ys3 536.244



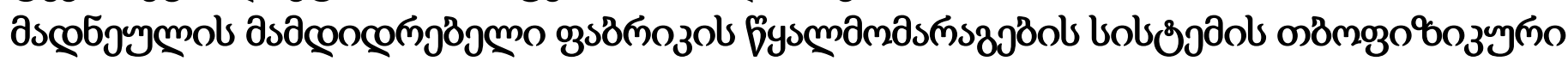
zss6zsmoð̄jas

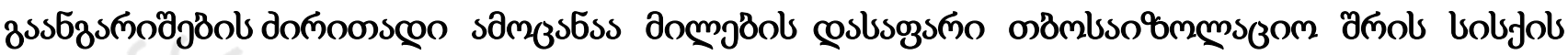

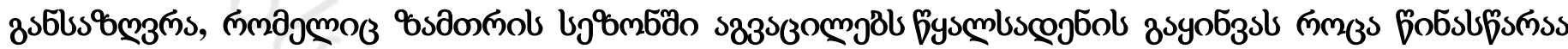

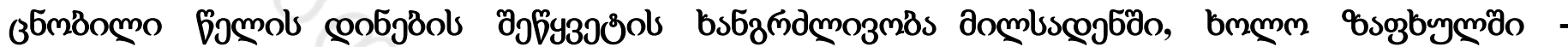

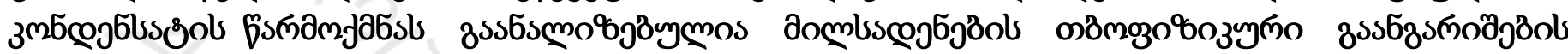

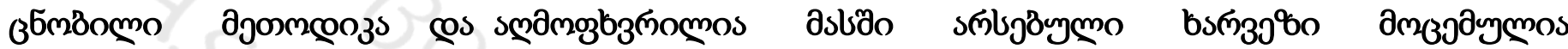

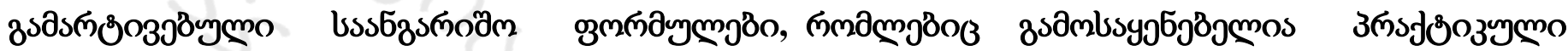

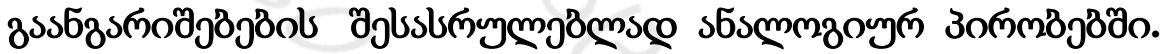







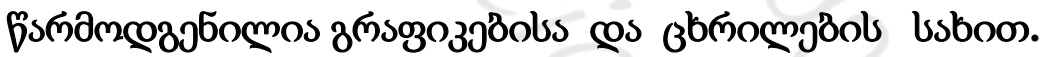

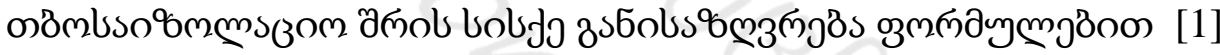

$$
\ln \frac{d_{3}}{d_{2}}=2 \pi \lambda_{2}\left[\frac{3,6 L k}{G c \ln \frac{t_{1}-t_{0}}{t_{2}-t_{0}}}-\left(\frac{\ln \frac{d_{2}}{d_{1}}}{2 \pi \lambda_{1}}-\frac{1}{\alpha \pi d_{3}}\right)\right] \text {, (1) }
$$

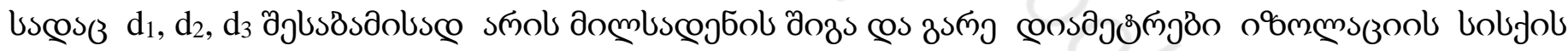

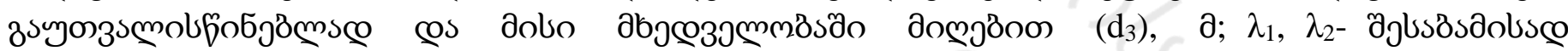

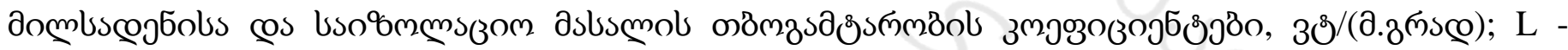



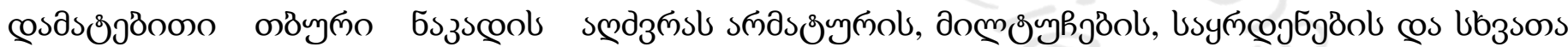

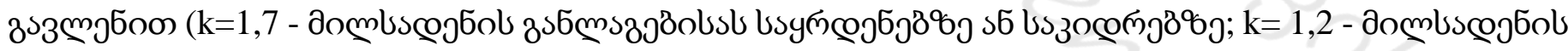



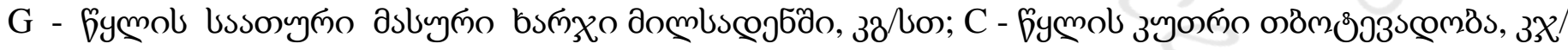



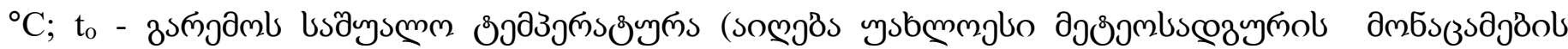

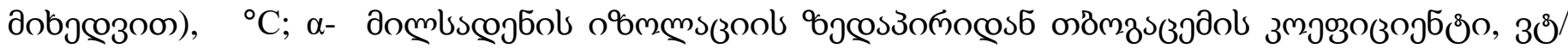

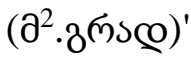



$$
\delta_{3}=\frac{d_{3}-d_{2}}{2} .
$$

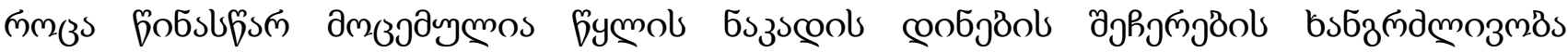

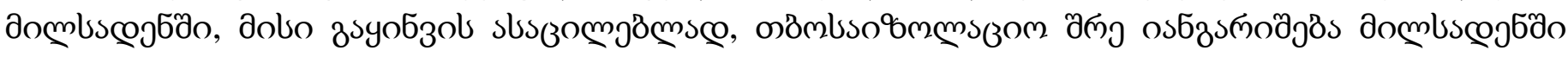




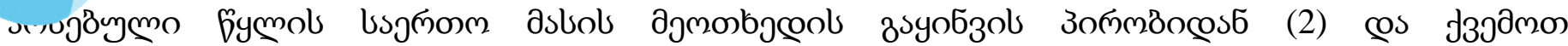

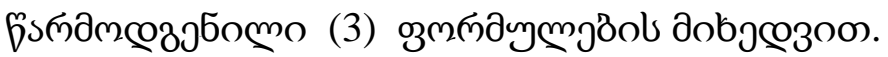

$$
\begin{aligned}
& \ln \frac{d_{3}}{d_{2}}=2 \pi \lambda_{2} \times \\
& \times\left[\frac{3,6 z k}{\left(v \rho c+v_{1} \rho_{1} c_{1}\right) \ln \frac{t_{1}-t_{0}}{t^{\prime}-t_{0}}+\frac{0,25 v \rho r}{t^{\prime}-t_{0}}}-\frac{\ln \frac{d_{2}}{d_{1}}}{2 \pi \lambda_{1}}+\frac{1}{\alpha d_{3} \pi}\right],
\end{aligned}
$$

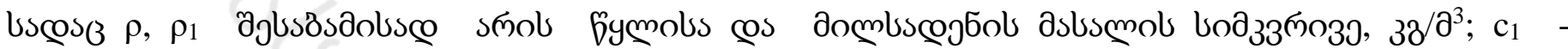

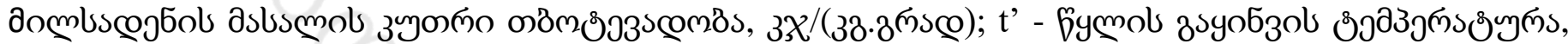

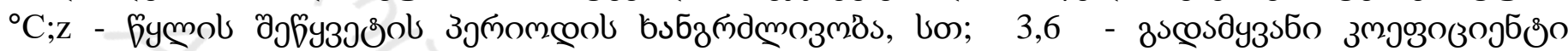

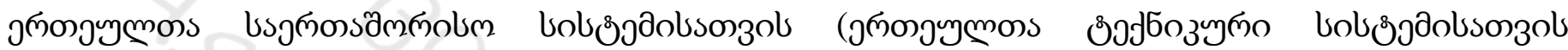

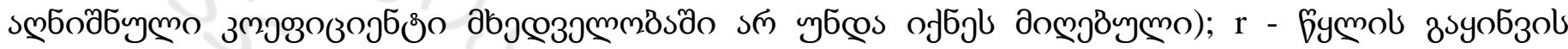

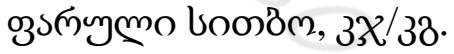

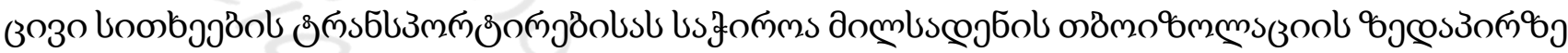

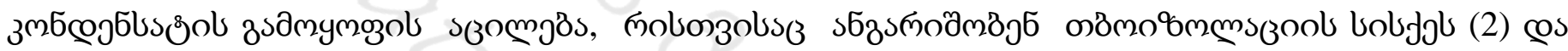

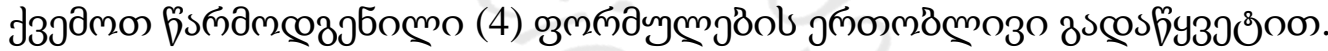

$$
\frac{d_{3}}{d_{2}} \ln \frac{d_{3}}{d_{2}}=\frac{2 \lambda_{2}}{d_{2} d_{3}}\left(\frac{t_{0}-t_{T}}{t_{0}-t_{\Pi}}-1\right),
$$

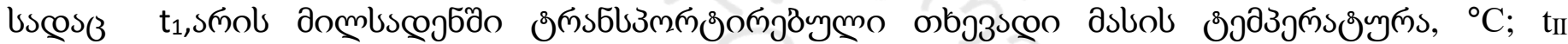

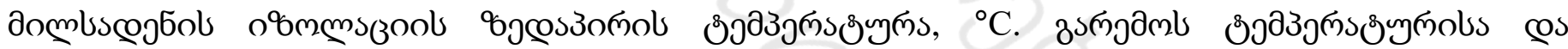

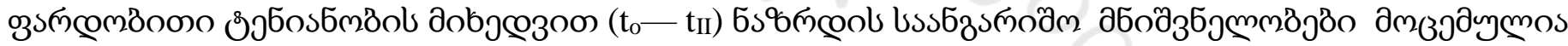

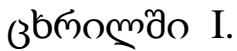

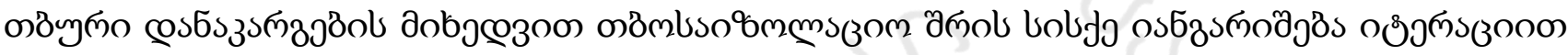

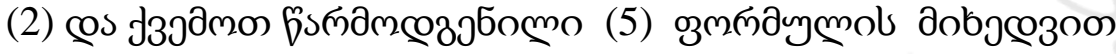

$$
\ln \frac{d_{3}}{d_{2}}=2 \pi \lambda_{2} \frac{t_{T}-t_{0}}{q}\left(\frac{\ln \frac{d_{2}}{d_{1}}}{2 \pi \lambda_{1}}+\frac{1}{\alpha d_{3} \pi}\right)
$$

\begin{tabular}{|c|c|c|c|c|c|}
\hline \multirow[b]{2}{*}{ № } & \multirow{2}{*}{ 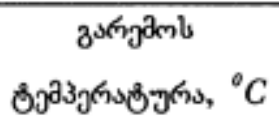 } & \multicolumn{4}{|c|}{ 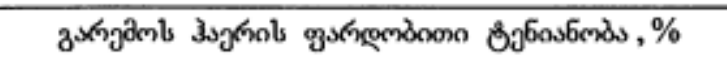 } \\
\hline & & 50 & 60 & 70 & 80 \\
\hline 1. & 20 & 10,7 & 8,0 & 5,6 & 3,6 \\
\hline 2. & 25 & 11,1 & 8,3 & 5,8 & 3,7 \\
\hline 3. & 30 & 11,6 & 8,6 & 6,1 & 3,8 \\
\hline
\end{tabular}

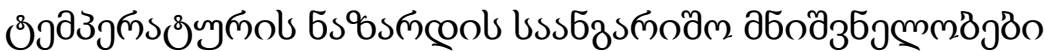

3b̆омmo 1 


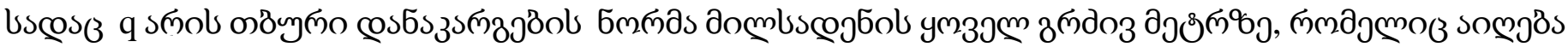

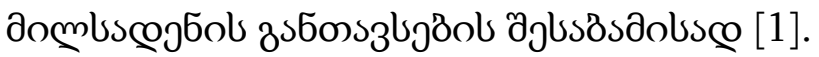

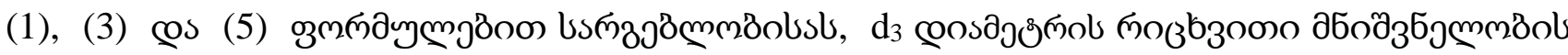

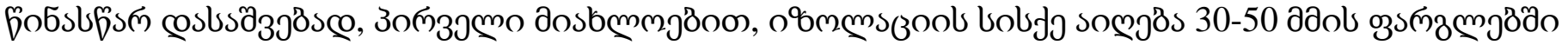

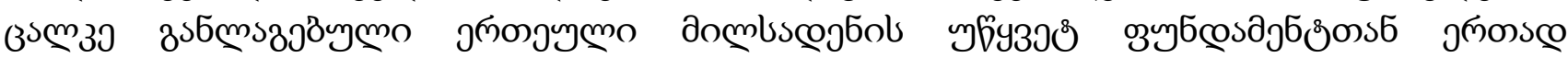

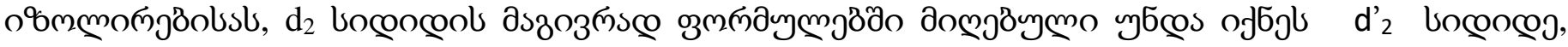

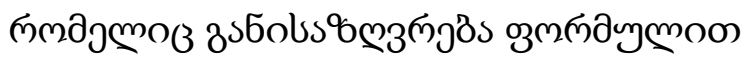

$$
d_{2}^{\prime}=\frac{P}{\pi}
$$

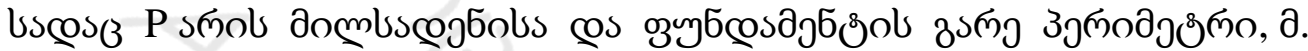

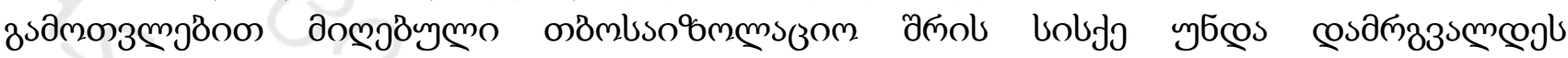

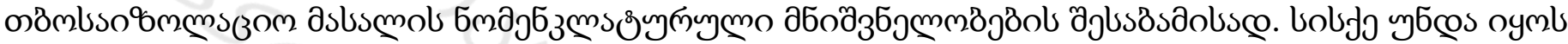

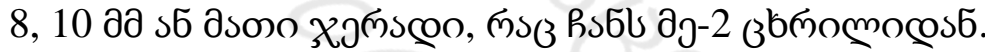

3bromo 2

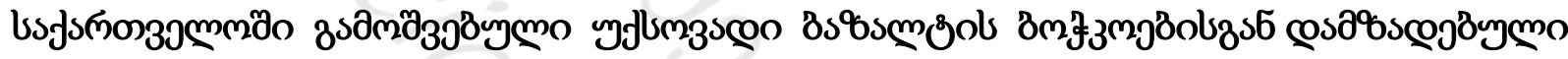

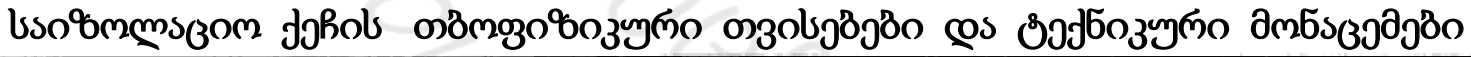

\begin{tabular}{|c|c|c|c|c|c|c|}
\hline 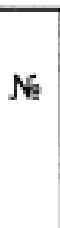 & $2 \operatorname{minj}_{j}$ & $\begin{array}{c}\text { bolida. } \\
\text { aa }\end{array}$ & 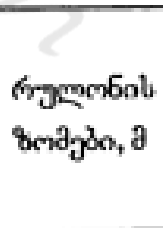 & 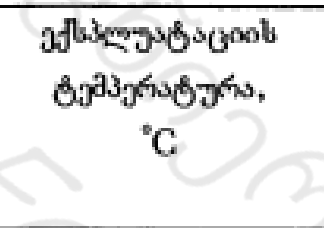 & 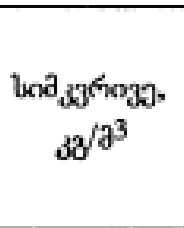 & 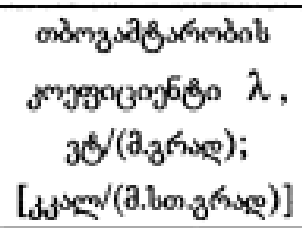 \\
\hline 1. & t5 $88-1000$ & 8 & $1 \mathrm{X} 10$ & -260 ख & 125,0 & $\begin{array}{c}0,032-0,038 \\
{[0,028-0,035]}\end{array}$ \\
\hline 2. & J73 10-1500 & 10 & $1 \mathrm{X} 10$ & -260 - ए5: & 150,0 & $\begin{array}{c}0,032-0,038 \\
{[0,028-0,035]}\end{array}$ \\
\hline 3. & $5988-1000_{9}$ & 8 & $1 \times 10$ & 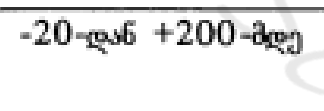 & 125,0 & $\begin{array}{c}0,032-0,038 \\
{[0,028-0,035]}\end{array}$ \\
\hline
\end{tabular}

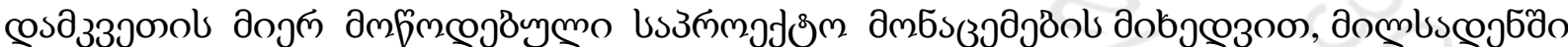

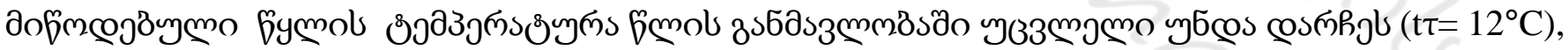

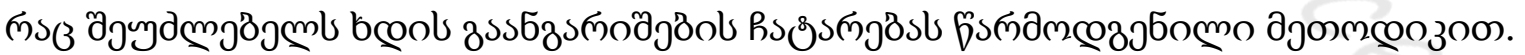

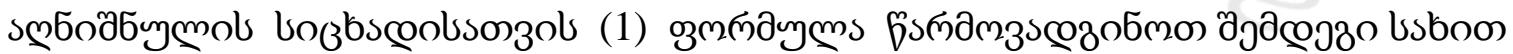

$$
\ln \frac{d_{3}}{d_{2}}=2 \pi \lambda_{2}(A-B+C) \text {, }
$$

bscosos

$$
A=3,6 L k / G c \ln \frac{t_{1}-t_{0}}{t_{2}-t_{0}} ; B=\ln \frac{d_{2}}{d_{1}} / 2 \pi \lambda
$$




$$
C=\frac{1}{\alpha \pi d_{3}}
$$

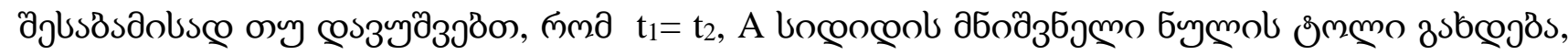

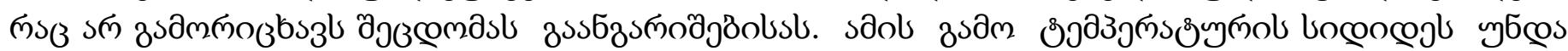

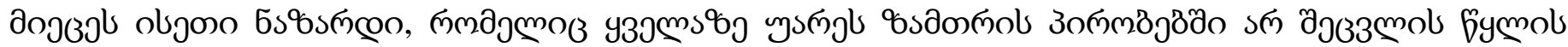

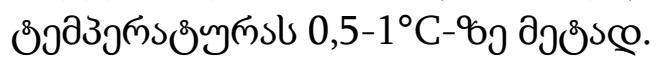

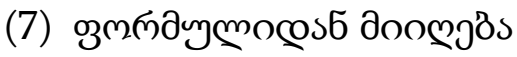

$$
\ln d_{3}=\ln d_{2}+2 \pi \lambda_{2}(A-B-C)
$$

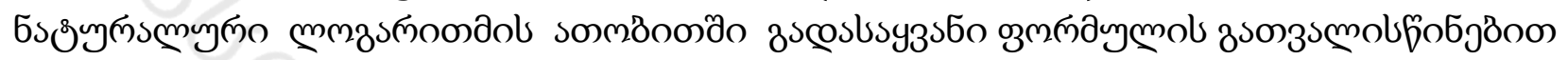

$$
\ln N=\frac{\lg N}{\lg e} \approx \frac{\lg N}{0,43429}
$$

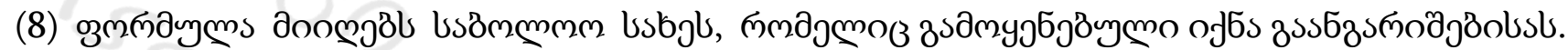

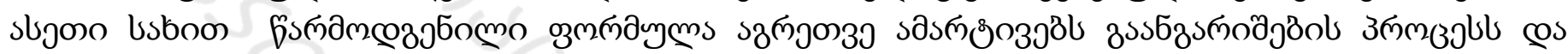

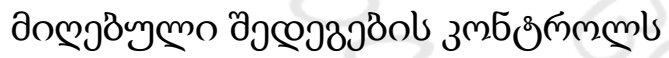

$$
\lg d_{3} \approx 0,43429\left[\ln d_{2}+2 \pi \lambda_{2}(A-B-C)\right]
$$

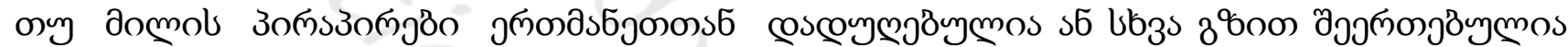

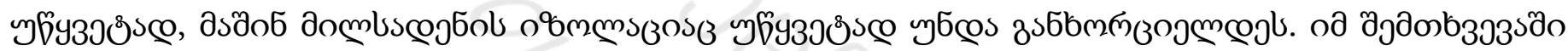

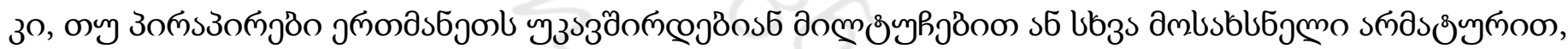

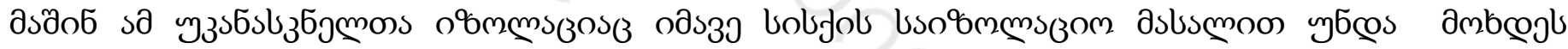

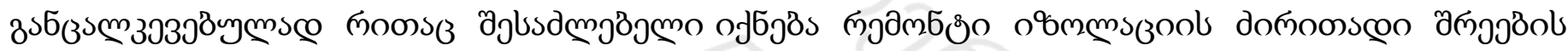
cosyoosbj8̈msco.

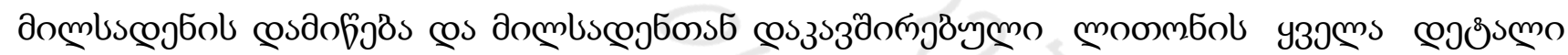

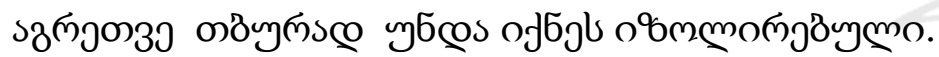

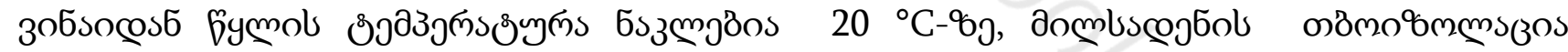

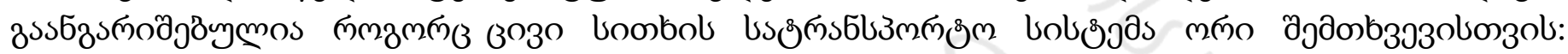

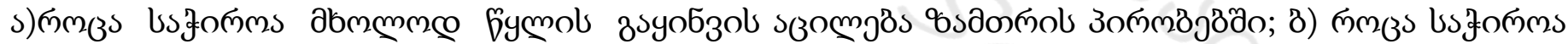

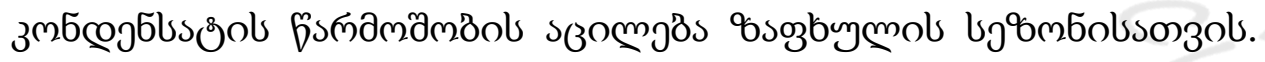




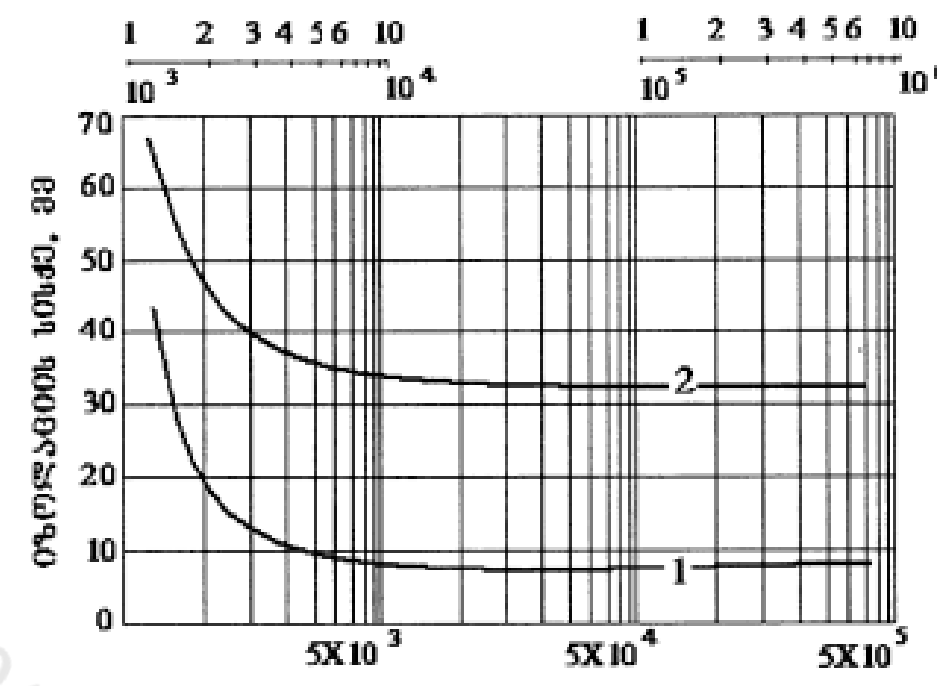

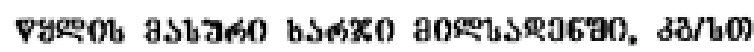

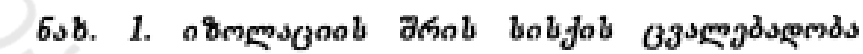

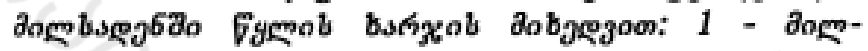

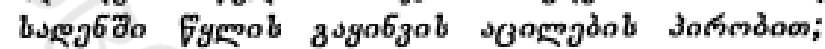

2 - дощ

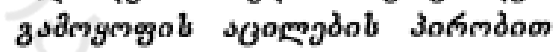

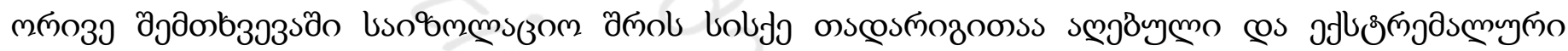

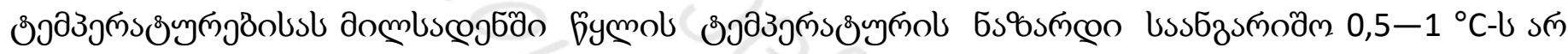

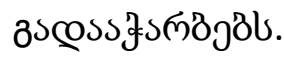

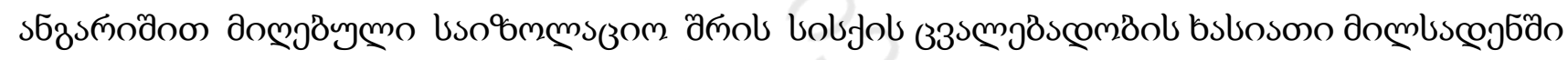

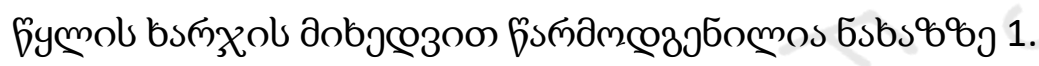

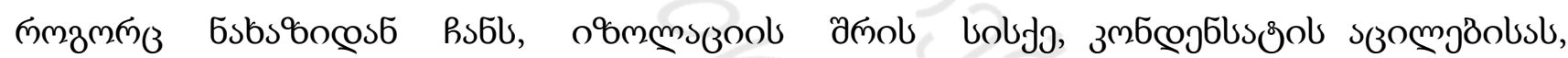

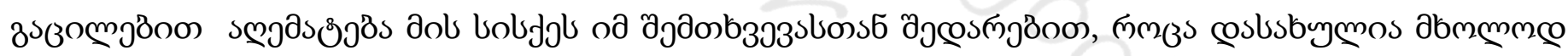

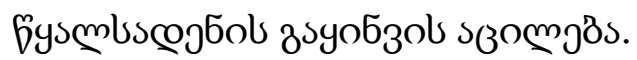

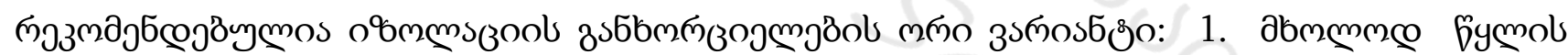

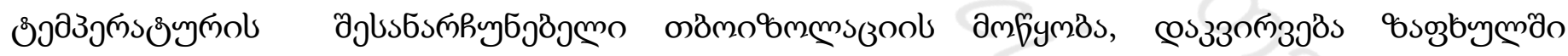

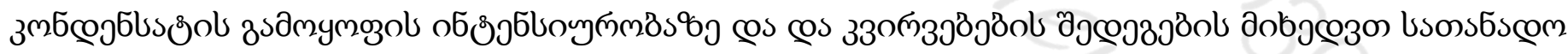

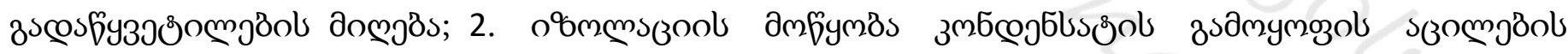

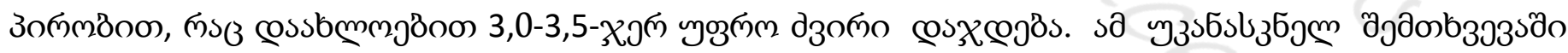

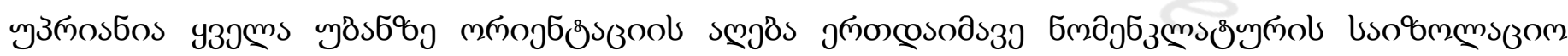

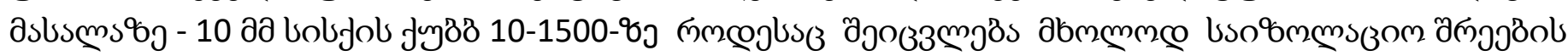

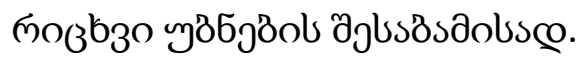

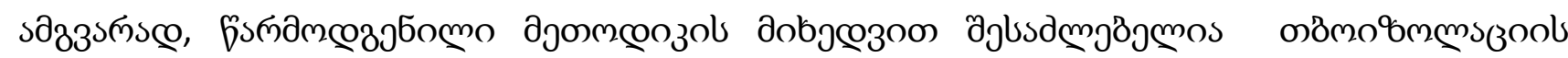

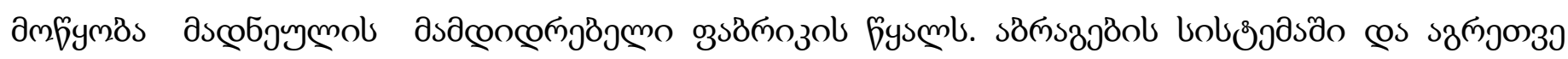

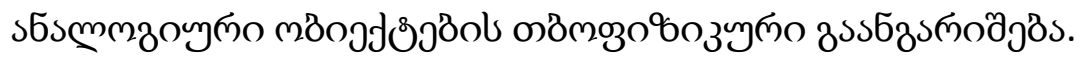

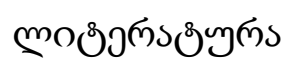

1. Проектирование, строительство и эксплуатация трубопроводов из полимерных материалов.

Под редакцией А. И. Шестопала и ВС Ромейко.Москва, Стройиздат, 1985. 304 с. 
hava $\mathrm{O}$

\section{THERMAL CALCULATION OF A SYSTEM OF WATERSUPPLY OF CONCENTRATOR OF MADNEULI}

The basic problem of the presented thermal protection of system of water-supply is estimation of heat isolations coating-thickness. There is to address an issue to determination of system of water-supply of concentrator of Madneuli that has been deleted frost-back of trunk pipeline in winter season and sweating on the surface of pipeline in summer season. The method of calculation has been analysed and a light formula of thermal calculation has been produced that has been eased control of calculating results.

The coating-thickness has been in conformity with nomenclature of Georgian products of thermal protection materials. The thickness must be multiple $8,10 \mathrm{~mm}$ or of combination of them.

A basic research's result of mentioned object has been illustrated for tables and graphics. The results of calculation are given in the form of tables and graphics.

Ланчава О. А.

\section{ТЕПЛОФИЗИЧЕСКИЙ РАСЧЕТ СИСТЕМЫ ВОДОСНАБЖЕНИЯ МАДНЕУЛСКОЙ ОБОГАТИТЕЛЬНОЙ ФАБРИКИ}

Основной задачей данного теплофизического расчета является определение толщины теплоизоляции, которая даст возможность в зимнем сезоне избегать обмерзания водопровода, когда промежуток времени прекращения движения воды в водопроводепредварительно заданная величина, а летом - образования конденсата на поверхности трубопровода.Выполнен анализ известной методики теплофизического расчета и устранен ее недостаток. Приведены упрощенные формулы, которые рекомендуются для применения в аналогичных условиях.

Полученная в результате расчета толщина теплоизоляционного слоя необходимо Округлять в соответствии с номенклатурой выпуСКаемой в Грузии теплоизоляционного материала. Отмеченная толщина должна быть кратной 8, 10 ММ, или их комбинаций. Результаты расчета представлены в виде графиков и таблиц. 